J. Amer. Soc. Hort. Sci. 115(6):872-877. 1990.

\title{
Comparison of Sod, Mulch, Cultivation, and Herbicide Floor Management Practices for Grape Production in Nonirrigated Vineyards
}

\author{
R.M. Pool ${ }^{1}$, R.M. Dunst ${ }^{2}$, and A.N. Lakso ${ }^{1}$ \\ Department of Horticultural Sciences, New York State Agricultural Experiment Station, Cornell \\ University, Geneva, NY 14456 \\ additional index words. Vitis, grape, floor management, glyphosate, tillage
}

\begin{abstract}
In two 4-year studies, 'Concord' (Vitis labruscana, Bailey) cane pruning weight, yield, and soluble solids content were similar for vines growing under herbicide and cultivation treatments. In a vineyard with shallow soil, vines grown under mulch had a significantly greater increase in cane pruning weight than did vines grown with sod middles. Growth suppression of sod-managed vines occurred only in relatively dry years. While there was annual variation in vine response to herbicide and cultivation treatments, the cumulative responses over the 4-year study were similar for these treatments. A second vineyard where soil was less restrictive for root growth did not respond to the replacement of clean cultivation with herbicide treatments. In both experiments, there was no apparent advantage of two instead of a single herbicide application, and there was no difference between the budbreak, as opposed to bloom timing, of herbicide application.
\end{abstract}

The competitive effects of permanent sod row middles on 'Concord' grapevine productivity have been well documented (Fleming and Alderfer, 1956; Shaulis and Steele, 1969). While short-term vineyard productivity is usually greater with cultivation than with sod management, the deleterious effects of long-term cultivation in vineyards have been recognized for many years (Wander, 1946). Long-term vineyard yield declines have been attributed to decreased organic matter and $\mathrm{N}$ supply and to reduced soil permeability associated with continuous cultivation. Shaulis and Steele (1969) recognized that root pruning from cultivation of row middles or under the trellis might cause long-term damage to grapevines.

Decrease in vineyard productivity associated with sod middles occurred primarily in dry years (Fleming and Alderfer, 1956); hence, Fleming and Alderfer recommended a system of incomplete or trashy cultivation, in which partial weed cover is maintained in the vineyard at all times for non- or moderately eroded sites. With that system, near maximal vineyard productivity was achieved, and soil and water losses due to runoff and erosion were greatly reduced, as was the gradual decline in soil organic matter associated with continuous cultivation. For highly eroded sites, a rotation method was recommended, in which a sod cover is established for 2 or 3 years, followed by several years of cultivation. Sod affected vine growth only so long as competition was present. With the resumption of clean cultivation following the sod cover, vine growth and yield increased to compensate for the reduction that occurred when sod was present.

Before the development of chemicals to control competing weed growth, the only alternative to cultivation for weed control in 'Concord' production was mulching. Mulching often increases vine size and vineyard productivity (Beattie, 1955). No

Received for publication 10 Nov. 1989. Research was supported in part by grants from the New York State Grape Production Research Fund, Inc., and the New York Grape and Wine Foundation. We acknowledge the contributions of Christine Cummings and John Ryder, who provided technical assistance, and Richard Erdle, who provided the research site. The cost of publishing this paper was defrayed in part by the payment of page charges. Under postal regulations, this paper therefore must be hereby marked advertisement solely to indicate this fact.

'Professor.

${ }^{2}$ Research Support Specialist, Vineyard Laboratory, Fredonia, N.Y. tillage provides another alternative to cultivation for many crops. No tillage with herbicides offers several advantages over conventional tillage methods (Phillips, 1981), including reduced erosion and soil compaction, improved moisture status due to reduced evaporation, increased percolation rates, and reduced energy costs and equipment requirement. Soils managed with no-tillage systems for extended periods generally have higher soil organic matter content than do tilled soils. (Blevins et al., 1984).

Vineyard no tillage has been studied extensively in South Africa. After 8 years under dry land conditions, Van Huyssteen and Weber (1980a, 1980b) found that Vitis vinifera vines growing under no tillage or mulch outperformed those under clean cultivation or sod ("permanent sward"), as measured by root density, shoot growth rate, cane pruning weight, and grape yield. In that study, and others that gave similar results (Morlat et al., 1984; Remoue and LeMaitre, 1985; Wilson, 1985), no-tillage treatments used pre-emergence herbicides to control weeds throughout the growing season.

The favorable results from areas with Mediterranean climates (Elia and Gay, 1985; Morlat et al., 1985) suggest that no tillage might be a useful alternative to trashy cultivation for 'Concord' vineyards growing under the summer rainfall conditions of New York state. Two 4-year studies were conducted from 1984 to 1987 in Chautauqua County, N. Y., comparing the impact of no tillage, using nonpersistent herbicides, with that of traditional vineyard floor management practices on vine growth and productivity. One experiment compared three herbicide treatments with two cultivation methods (permanent sod and mulch) in a vineyard where soil depth restricted root growth. A second experiment compared three herbicide treatments with clean cultivation in a vineyard where the potential for deep (> $6 \mathrm{~m}$ ) root growth was possible.

\section{Materials and Methods}

Herbicides, cultural methods, restricted root growth (Expt. 1). The first experiment was conducted in an umbrella Kniffintrained vineyard near Silver Creek, N.Y. The soil was a Barcelona silt loam, somewhat poorly drained, with a siltstone and shale substratum $\approx 0.5 \mathrm{~m}$ deep. The soil has a high available water capacity, a moderately slow permeability in the silty man- 
tie, and a slow permeability in the substratum. The vineyard was planted about 1950 and was clean-cultivated until 1982. In 1983, a permanent sod was encouraged to control erosion, but the owner became concerned about an apparent loss of vine size. The experiment was initiated during Winter 1983-84 using a randomized complete-block (RCB) design with five blocks. Floor management treatments were assigned using 12 vines (30 $\mathrm{m}$ of row) per plot. Vine performance data was recorded for the middle $15 \mathrm{~m}$. Vines with initial cane pruning weight of $<0.25$ $\mathrm{kg}$ and those that showed visible trunk injury from winter damage or Eutypa dieback infection were excluded. Vines were spaced $2.4 \mathrm{~m}$ apart in rows $2.7 \mathrm{~m}$ apart. The count vines for which vine performance data were collected were established in every third vineyard row; experimental treatments were applied on both sides of count vines. Floors in barrier rows received a single glyphosate application and were mown as needed. Vine growth was assessed by weighing cane prunings. Vines were balance-pruned to a $20+20$ scale $(20$ nodes retained per 0.5 $\mathrm{kg}$ of cane prunings) in the 1983-87 dormant seasons. Juice soluble solids content (SSC) and berry weights were determined by sampling just before harvest. Clusters were counted and weighed at harvest. Petiole samples were taken for each plot in years 2 and 4 . Vineyard management was based on recommended methods (Jordan et al., 1980). Ammonium nitrate was applied at $100 \mathrm{~kg}$ actual N/ha per year. Weed growth under the trellis was controlled with N'-(3,4-dichlorophenyl) -N, N-dimethylurea (diuron) in 1984, with a mixture of diuron and 6chloro-N,N'-diethyl-1,3,5 -triazine-2,4-diamine (simazine) in 1985 and 1986, and with simazine alone in 1987. Glyphosate was applied under the trellis in most years to keep the 0.9-m band under the trellis free of competitive weed growth.

Seven vineyard floor management treatments were applied annually from 1984 to 1987 : 1) Permanent sod: Row middles were mown five times at monthly intervals during May through September. An $85 \%$ to $95 \%$ ground cover of weeds was present throughout the season, divided about equally between perennial grasses and perennial broadleaf weeds. Primary weeds included quackgrass (Agropyron repens L.), orchardgrass (Dactylis glomerata L.), perennial ryegrass (Lolium perenne L.), common dandelion (Taraxacum officinale Weber), and broadleaf plantain (Plantago major L.). 2) Clean cultivation: Plots were cultivated three times annually during May through July to a depth of 3 to $5 \mathrm{~cm}$. Weeds were essentially eliminated using multiple cultivation passes. Weed populations from April to June were mainly Kentucky bluegrass (Pea pratensis L.); from June to October weeds were primarily large crabgrass (Digitaria sanguinalis L.). Perennials were effectively controlled by the repeated cultivation. 3) Trashy cultivation: Weed ground cover was kept in the range of $10 \%$ to $40 \%$ by three single-pass cultivations to a depth of 3 to $5 \mathrm{~cm}$ during May through July. Weed species present included dandelion, plantain, orchardgrass, perennial ryegrass, quackgrass, and crabgrass. 4) Mulch: Oat straw was applied in the row middles in April, before weed growth, at 9 to $10 \mathrm{t} \cdot \mathrm{ha}^{-1} \cdot$ year $^{-1}$, giving an initial mulch depth in excess of $15 \mathrm{~cm}$. Weed growth consisted of a $5 \%$ to $10 \%$ cover of dandelion, orchardgrass, quackgrass, and oats, which germinated from seed introduced with the straw. These weeds were mown in July. An additional three herbicide treatments used glyphosate applied at $2 \mathrm{~kg}$ a.i./ha. Perennial grasses were absent from these treatments following the first-year application of glyphosate. Annual grasses, primarily large crabgrass with smaller amounts of yellow foxtail [Setaria glauca (L.) Beauv.] and barnyardgrass [Echinochlloa crusgalli (L.) Beauv.], were the primary weed cover following herbicide application. These weeds were killed by frost in late October. 5) Budbreak herbicide: Weed growth, primarily dandelion and plantain, was eliminated at or shortly after budbreak with glyphosate in early to midMay. Annual grasses germinated soon after herbicide application, with a $50 \%$ ground cover established by early June and $80 \%$ to $90 \%$ by early July. Weeds were mown in July and August. 6) Bloom herbicide: Weed cover was $30 \%$ crabgrass and $10 \%$ perennials, mainly dandelion and plantain, at the time of glyphosate application in mid-June. Annual grasses germinated in late June and covered $50 \%$ of the ground by mid-July. A single mowing before herbicide application was necessary only in the first year of the experiment due to the presence of orchardgrass, quackgrass, and perennial ryegrass. In all years, this treatment was mown in August. 7) Budbreak plus bloom herbicide: Weed growth was eliminated at both application dates. Early season weed competition was minimal. After bloom, weed growth and mowing were similar to the bloom only herbicide treatment.

Herbicides, clean cultivation, deep root growth Expt. 2). A companion study was initiated at the Vineyard Laboratory of the New York State Agricultural Experiment Station in Fredonia, N.Y. The soil was a Chenango gravelly loam-a very deep, well-drained soil formed in water-sorted outwash material. Available water was low, with moderate to moderately high permeability in the subsoil and high permeability in the substratum. The vineyard received annual clean cultivation since its establishment in 1956. Treatments established during Winter 1983-84 included clean cultivation, budbreak herbicide, bloom herbicide, and budbreak plus bloom herbicide. Before establishment of the floor management treatments, the vineyard had been used for a cane length and shoot-positioning experiment. Treatment effects from the previous experiment probably accounted for most of the variability in vine size at the initiation of the experiment (see Table 6.) A RCB design was used with four blocks of three experimental vines in each of two adjacent rows. Vine and row spacing was the same as for Expt. 1. Plots were separated by a barrier of $7.3 \mathrm{~m}$, one-half of which was treated as per the adjacent plot. Two blocks were established on vines with nondivided high cordon training (Hudson River Umbrella, HRU), and two on high cordon divided canopy vines (Geneva Double Curtain, GDC), so each treatment consisted of 24 count vines. Blocks were separated by barrier rows. Vineyard management was similar to that described in Expt. 1, except ammonium nitrate was applied at $87 \mathrm{~kg}$ actual N/ha per year. Under the trellis, weeds were controlled using diuron and simazine; glyphosate was used as a spot treatment in most years to keep the $0.9-\mathrm{m}$ band free of competitive weed growth. Vines were balance-pruned to a $20+20$ scale, and harvest samples were collected in the manner described for Expt. 1.

Mean separations were made using Duncan's multiple range test at $P=0.05$. Pooled single herbicide treatments and trashy cultivation were selected for contrasts, as they represent commercial standards.

\section{Results}

\section{Experiment 1}

1984. There was some variation in vine size at the initiation of the experiment (Table 1), which was primarily related to variations in the organic matter content of the soil in individual plots (data not shown). Treatments using herbicides resulted in 
Table 1. Weight and change in weight of cane prunings $(\mathrm{kg})$ per vine of 'Concord' grapevines growing under various floor management practices at the Erdle Vineyard, Silver Creek, N.Y.

\begin{tabular}{|c|c|c|c|c|c|c|c|c|c|c|}
\hline $\begin{array}{l}\text { Floor } \\
\text { management }\end{array}$ & $\begin{array}{c}1983 \\
\text { Grown }\end{array}$ & $\begin{array}{r}1984 \\
\text { Grown } \\
\end{array}$ & $\begin{array}{l}\text { Change } \\
1983-84 \\
\end{array}$ & $\begin{array}{c}1985 \\
\text { Grown } \\
\end{array}$ & $\begin{array}{r}\text { Change } \\
1984-85 \\
\end{array}$ & $\begin{array}{r}1986 \\
\text { Grown } \\
\end{array}$ & $\begin{array}{l}\text { Change } \\
1985-86 \\
\end{array}$ & $\begin{array}{r}1987 \\
\text { Grown } \\
\end{array}$ & $\begin{array}{l}\text { Change } \\
1986-87 \\
\end{array}$ & $\begin{array}{l}\text { Change } \\
1983-87 \\
\end{array}$ \\
\hline Sod & $0.71 a b^{z}$ & $0.79 \mathrm{ab}$ & $0.08 \mathrm{bc}$ & $0.73 \mathrm{c}$ & $-0.08 c$ & 1.19 & $0.46 \mathrm{a}$ & $1.04 \mathrm{~b}$ & $-0.15 b$ & $0.34 \mathrm{~b}$ \\
\hline ras & $a b$ & 0. & 0 & $a b$ & $a b$ & 1.22 & & $a b$ & $02 \mathrm{~b}$ & $7 \mathrm{ab}$ \\
\hline Cles & 0 & $b$ & bc & $0.83 \mathrm{bc}$ & & 1.2 & & 1. & $37 b$ & a \\
\hline Mu & & & & 1 & & 1. & & 1.3 & $0 \mathrm{a}$ & a \\
\hline Budbreak hert & $a b$ & a & & $0.89 \mathrm{ab}$ & c & 1. & & $1.27 \mathrm{ab}$ & $55 \mathrm{~b}$ & a \\
\hline Bloom herbicide & $0.70 \mathrm{ab}$ & $0.93 \mathrm{a}$ & $0.23 \mathrm{a}$ & $0.95 \mathrm{ab}$ & $0.03 \mathrm{bc}$ & 1.33 & & $1.26 \mathrm{ab}$ & $-0.07 b$ & $0.56 \mathrm{a}$ \\
\hline 3udbreak + & & & & & & & & & & \\
\hline bloom herbicide & $0.59 \mathrm{~b}$ & $0.80 \mathrm{ab}$ & $0.21 \mathrm{a}$ & $0.80 \mathrm{bc}$ & $0.00 \mathrm{c}$ & 1.24 & $0.45 \mathrm{a}$ & $1.15 \mathrm{ab}$ & $-0.10 b$ & $0.56 \mathrm{a}$ \\
\hline
\end{tabular}

'Mean separation within columns by Duncan's multiple range test, $\mathrm{P}=0.05$.

greater increases in cane prunings from 1983 to 1984 than found in the cultivation or sod treatments. Mulching resulted in an intermediate pruning weight increase that was similar to the herbicide treatments, sod, and clean cultivation. There were no significant differences in yield or juice SSC in 1984 (Table 2).

1985. Budbreak glyphosate-treated vines had higher yields than did clean- or trashy-cultivated vines (Table 2). Single-degree-of-freedom contrast testing the effect of the pooled single herbicide treatments against the other individual treatments showed glyphosate treatments resulted in higher yield than did the sod $(P=0.0098)$ or cultivation $(\mathrm{P}=0.0467)$ treatments. Juice SSC were all commercially acceptable, but were significantly higher with sod than with mulch, possibly due to diuron injury and $\mathrm{Mg}$ deficiency observed on mulched vines (Table 3), which may have reduced late-season sugar production. Herbicide and cultivation treatments produced intermediate SSC values. Even though higher yields were obtained with herbicide treatments, there was little change in cane prunings (Table 1). Cane pruning weight increases from 1984 to 1985 were greater for vines of cultivation treatments than for the budbreak and budbreak plus bloom herbicide treatments. Mulch and cultivation treatments resulted in greater cane pruning weight increases, as compared to sod. Single herbicide treatments, trashy cultivation, and mulch had significantly greater cane prunings than did sod.

1986. Mulched vines outyielded all, except those receiving trashy cultivation in 1986, and had the lowest SSC at harvest. Mulch and trashy cultivation vines had higher yields than vines of clean cultivation, sod, and the budbreak plus bloom herbicide treatment (Table 2). Cane pruning weight increase was signifi icantly lower for mulched vines than for any other treatment (Table 1). Differences in vine size (cane pruning weight) exist- ing after year 2 (1985) were no longer apparent after the third treatment growing season. This result may primarily be an effect of abundant soil moisture in 1986, as growing season precipitation was $69 \%$ greater than the 30 -year average (Table 4 ).

1987. There were no differences among treatments in yield or SSC in 1987 (Table 2). Cane pruning weights increased only for mulched vines during 1987 (Table 1), and this increase was significantly larger than found with any other treatment. At the end of the experiment in 1987, all vines had satisfactory cane pruning weights, and those of mulched treatments were significantly larger than those of vines with sod-row middles.

Four-year summary. There were no significant differences among treatments in cumulative yield for 1984 through 1987 (Table 2). During that period, cane pruning weight increased for all treatments. All treatments, except trashy cultivation, had a greater increase in cane pruning weight than vines in sod plots (Table 1). There were no significant differences in cane pruning weight or yield for the duration of the experiment among herbicide treatments using budbreak, bloom, or budbreak plus bloom applications.

Leaves on all vines were evaluated at harvest in years 2-4 for specific deficiency symptoms, for injury from diuron, and for senescence (Table 3). Degree of senescence (percent of leaves appearing senescent) was generally similar for herbicide and cultivated treatments. Sod vines had the highest senescence percentages, even in years with low yields. The impact of mulching is indicated by less senescence and the presence of diuron injury symptoms in years 2 and 3. Mulching also was associated with the presence of $\mathrm{Mg}$ deficiency symptoms that appeared in year 2. Magnesium deficiency was somewhat less on mulched vines in years 3 and 4, following two annual foliar applications of

Table 2. Yield and juice soluble solids content (SSC) of 'Concord' grapevines growing under various floor management practices at the Erdle Vineyard, Silver Creek, N. Y.,

\begin{tabular}{|c|c|c|c|c|c|c|c|c|c|}
\hline \multirow[b]{2}{*}{$\begin{array}{l}\text { Floor } \\
\text { management }\end{array}$} & \multicolumn{2}{|c|}{1984} & \multicolumn{2}{|c|}{1985} & \multicolumn{2}{|c|}{1986} & \multicolumn{2}{|c|}{1987} & \multirow{2}{*}{$\frac{1985-1987}{\begin{array}{c}\text { Cumulative yield } \\
\left(\mathrm{t} \cdot \mathrm{ha}^{-1}\right)\end{array}}$} \\
\hline & $\begin{array}{c}\text { Yield } \\
\left(\mathrm{t} \cdot \mathrm{ha}^{-1}\right)\end{array}$ & $\begin{array}{c}\mathrm{SSC} \\
(\%)\end{array}$ & $\begin{array}{c}\text { Yield } \\
\left(\mathrm{t} \cdot \mathrm{ha}^{-1}\right)\end{array}$ & $\begin{array}{l}\text { SSC } \\
(\%)\end{array}$ & $\begin{array}{c}\text { Yield } \\
\left(\mathrm{t} \cdot \mathrm{ha}^{-1}\right)\end{array}$ & $\begin{array}{l}\text { SSC } \\
(\%)\end{array}$ & $\begin{array}{c}\text { Yield } \\
\left(\mathrm{t} \cdot \mathrm{ha}^{-1}\right)\end{array}$ & $\begin{array}{l}\text { SSC } \\
(\%)\end{array}$ & \\
\hline$\overline{\text { Sod }}$ & 10.6 & 17.4 & $9.4 \mathrm{abc}$ & $17.9 \mathrm{a}$ & $10.7 \mathrm{c}$ & $16.2 \mathrm{a}$ & 20.6 & 15.7 & 38.6 \\
\hline Trashy cultivation & 11.1 & 16.5 & $8.8 \mathrm{bc}$ & $17.2 \mathrm{ab}$ & $13.8 \mathrm{ab}$ & $15.6 \mathrm{ab}$ & 18.1 & 15.4 & 40.7 \\
\hline Clean cultivation & 9.6 & 17.0 & $8.5 \mathrm{c}$ & $17.3 \mathrm{ab}$ & $11.1 \mathrm{c}$ & $16.5 \mathrm{a}$ & 17.6 & 15.2 & 37.2 \\
\hline Mulch & 11.5 & 16.9 & $10.3 \mathrm{abc}$ & $16.3 \mathrm{~b}$ & $15.4 \mathrm{a}$ & $14.7 \mathrm{~b}$ & 16.6 & 15.6 & 42.4 \\
\hline Budbreak herbicide & 9.4 & 17.6 & $11.9 \mathrm{a}$ & $17.2 \mathrm{ab}$ & $12.2 \mathrm{bc}$ & $16.1 \mathrm{a}$ & 19.6 & 15.6 & 43.7 \\
\hline Bloom herbicide & 10.3 & 16.9 & $11.3 \mathrm{ab}$ & $16.9 \mathrm{ab}$ & $12.7 \mathrm{bc}$ & $15.6 \mathrm{ab}$ & 17.8 & 15.4 & 41.8 \\
\hline $\begin{array}{l}\text { Budbreak }+ \\
\text { bloom herbicide }\end{array}$ & 9.7 & 17.4 & $11.0 \mathrm{abc}$ & $17.6 \mathrm{ab}$ & $11.2 \mathrm{c}$ & $16.3 \mathrm{a}$ & 18.7 & 15.2 & 40.9 \\
\hline
\end{tabular}

${ }^{7}$ Mean separation within columns by Duncan's multiple range test, $P=0.05$; lack of separation indicates nonsignificance.

'Dates of SSC determinations: 4 Oct. 1984, 27 Sept. 1985, 29 Sept. 1986, 16 Sept. 1987. 
Table 3. Effect of vineyard floor management on percent of leaves in late summer that showed symptoms of leaf sensecence, Mg deficiency, or diuron injury of 'Concord' grapevines in 3 years at the Erdle Vineyard, Silver Creek, N. Y.'

\begin{tabular}{|c|c|c|c|c|c|c|c|c|c|}
\hline \multirow[b]{2}{*}{$\begin{array}{l}\text { Floor } \\
\text { management }\end{array}$} & \multicolumn{3}{|c|}{1985} & \multicolumn{3}{|c|}{1986} & \multicolumn{3}{|c|}{1987} \\
\hline & Senescence & $\begin{array}{c}\mathrm{Mg} \\
\text { deficiency } \\
\end{array}$ & $\begin{array}{l}\text { Diuron } \\
\text { injury }\end{array}$ & Senescence & $\begin{array}{c}\mathrm{Mg} \\
\text { deficiency }\end{array}$ & $\begin{array}{c}\text { Diuron } \\
\text { injury }\end{array}$ & Senescence & $\begin{array}{c}\mathrm{Mg} \\
\text { deficiency }\end{array}$ & $\begin{array}{c}\text { Diuron } \\
\text { injury }\end{array}$ \\
\hline Sod & $24 \mathrm{a}$ & $1 \mathrm{~b}$ & $0 \mathrm{~b}$ & $31 \mathrm{a}$ & $3.0 \mathrm{bc}$ & $0 \mathrm{~b}$ & $34 \mathrm{a}$ & $0 \mathrm{~b}$ & 0 \\
\hline Trashy cultivation & $20 \mathrm{~b}$ & $1 \mathrm{~b}$ & $0 \mathrm{~b}$ & $26 \mathrm{~b}$ & $1.0 \mathrm{bc}$ & $0 \mathrm{~b}$ & $27 \mathrm{bc}$ & $0 \mathrm{~b}$ & 0 \\
\hline Clean cultivation & $19 \mathrm{~b}$ & $3 \mathrm{~b}$ & $0 \mathrm{~b}$ & $26 \mathrm{~b}$ & $0.0 \mathrm{c}$ & $0 \mathrm{~b}$ & $22 \mathrm{~d}$ & $0 \mathrm{~b}$ & 0 \\
\hline Mulch & $20 \mathrm{~b}$ & $44 \mathrm{a}$ & 1 a & $12 \mathrm{~d}$ & $24.0 \mathrm{a}$ & $5 \mathrm{a}$ & $28 \mathrm{~b}$ & $2 \mathrm{a}$ & 0 \\
\hline Budbreak herbicide & $22 a b$ & $2 \mathrm{~b}$ & $0 \mathrm{~b}$ & $25 \mathrm{bc}$ & $5.0 \mathrm{~b}$ & $0 \mathrm{~b}$ & $28 \mathrm{~b}$ & $0 \mathrm{~b}$ & 0 \\
\hline Bloom herbicide & $21 \mathrm{ab}$ & $1 \mathrm{~b}$ & $\mathrm{Ob}$ & $21 \mathrm{c}$ & $0.0 \mathrm{bc}$ & $0 \mathrm{~b}$ & $23 \mathrm{~cd}$ & $0 \mathrm{~b}$ & 0 \\
\hline Budbreak + & & & & & & & & & \\
\hline bloom herbicide & $24 a$ & $1 \mathrm{~b}$ & $0 \mathrm{~b}$ & $25 \mathrm{bc}$ & $0.0 \mathrm{c}$ & $0 \mathrm{~b}$ & 24 bcd & $0 \mathrm{~b}$ & 0 \\
\hline
\end{tabular}

'Mean separation within columns by Duncan's multiple range test, $P=0.05$.

Table '4. Growing season precipitation (mm) at Fredonia, N. Y., for the years 1984-87.

\begin{tabular}{lrrrrr}
\hline \hline Month & 1984 & 1985 & 1986 & 1987 & $\begin{array}{c}30 \text {-Year } \\
\text { mean }\end{array}$ \\
\hline May & 173 & 79 & 104 & 23 & 74 \\
June & 165 & 91 & 183 & 104 & 85 \\
July & 46 & 119 & 180 & 117 & 75 \\
August & 81 & 74 & 147 & 112 & 96 \\
September & 140 & 84 & 132 & 157 & 111 \\
May-September & 604 & 447 & 747 & 513 & 443 \\
Percent of mean & 136 & 101 & 169 & 116 & \\
\hline
\end{tabular}

Table 5. Mineral element concentration (\% dry weight) in 1985 and 1987 of 'Concord' petioles from vines grown under various floor management systems at the Erdle Vineyard, Silver Creek, N. Y.'

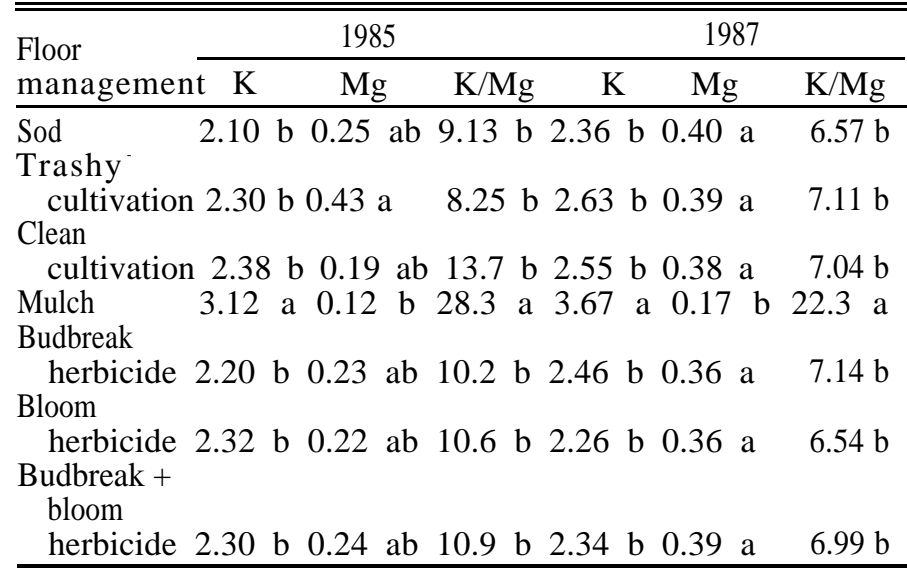

'Mean separation within columns by Duncan's multiple range test, $P$ $=0.05$.

epsom salts at $16 \mathrm{~kg} \cdot \mathrm{ha}^{-1}$. Petiole testing from samples collected after veraison in years 2 and 4 indicated $\mathrm{Mg}$ deficiency symptoms were associated with increased petiole concentration of $\mathrm{K}$ and decreased concentration of $\mathrm{Mg}$ in mulched vines (Table 5). Mulching was also associated with increased petiole concentrations of $P$ and $\mathrm{Mn}$ (data not shown). Petiole concentrations of nutrients was similar for vines of herbicide, cultivated, and sod treatments in both years.

\section{Experiment 2}

There were no differences in weight of cane prunings after the first year of the experiment (Table 6). Despite differences in vine size at the initiation of this experiment, there were no
Table 6. Weight and change in weight of cane prunings $(\mathrm{kg})$ per vine of 'Concord' grapevines growing under various floor management practices or training systems at the Vineyard Laboratory, Fredonia, N.Y., ${ }^{z, y}$

\begin{tabular}{llcr}
\hline \hline Floor & $1983^{2}$ & 1984 & $\begin{array}{c}\text { Change } \\
\text { management }\end{array}$ \\
\hline Grown & Grown & $1983-84$ \\
\hline Clean cultivation & $1.36 \mathrm{a}$ & 0.95 & $-0.41 \mathrm{~b}$ \\
Budbreak herbicide & $1.03 \mathrm{~b}$ & 1.03 & $0.00 \mathrm{a}$ \\
Bloom herbicide & $1.18 \mathrm{ab}$ & 1.01 & $-0.16 \mathrm{ab}$ \\
$\begin{array}{l}\text { Budbreak + } \\
\quad \text { bloom herbicide }\end{array}$ & $1.32 \mathrm{a}$ & 1,09 & $-0.23 \mathrm{~b}$ \\
$\begin{array}{l}\text { Training system } \\
\quad \text { Not divided }\end{array}$ & 1.09 & 0.95 & -0.14 \\
$\quad$ Divided & 1.32 & 1.09 & -0.23 \\
\hline
\end{tabular}

'Mean separation within columns by Duncan's multiple range test, $P$ $=0.05$; lack of separation indicates nonsignificance. The floor management $X$ training system interaction was not significant for any period.

Significant differences were absent for all factors in 1985-87.

significant treatment effects on yield for any year in the four years. There was some variation in juice SSC in the first year, but not in subsequent years (Table 7). There was significantly greater yield on GDC-trained vines in each year of the experiment, but no significant interactions between floor management treatment and training system were observed (Table 6). Yield increases with GDC were largely the result of increased fruitfulness (data not shown). There was no vine size penalty associated with the increased yield on GDC vines, but juice SSC were lower on GDC vines than on HRU vines in 1984 and 1987.

\section{Discussion}

Current vineyard floor management practices recommended for New York stem from research done during the previous 30 to 40 years. Recommended techniques are designed to balance conflicting goals of the vineyardist. The primary goal is to maintain a soil environment that will promote vigorous vegetative vine growth. To do this, the needs of both the vine and the characteristics of the site must be considered. Acceptable vine size is attained when 1) the soil depth, structure, and composition allows sufficient depth of rooting so that a large reservoir of nutrients and water is available to the vine and 2) those nutrients and water are not consumed excessively by competing vegetation.

In some situations, clean cultivation is a way to achieve these goals, but because many vineyards are planted on slopes, clean cultivation often leads to erosion and long-term loss of soil quality. 
Table 7. Crop per vine and juice soluble solids content (SSC) for 'Concord' grapevines grown under various floor management systems and two training systems at the Vineyard Laboratory, Fredonia, N.Y.

\begin{tabular}{|c|c|c|c|c|c|c|c|c|}
\hline \multirow[b]{2}{*}{$\begin{array}{l}\text { Floor } \\
\text { management }\end{array}$} & \multicolumn{2}{|c|}{1984} & \multicolumn{2}{|c|}{1985} & \multicolumn{2}{|c|}{1986} & \multicolumn{2}{|c|}{1987} \\
\hline & $\begin{array}{c}\text { Crop/vine } \\
(\mathrm{kg})\end{array}$ & $\begin{array}{l}\text { SSC } \\
(\%)\end{array}$ & $\begin{array}{c}\text { Crop/vine } \\
\text { (kg) }\end{array}$ & $\begin{array}{l}\text { SSC } \\
(\%) \\
\end{array}$ & $\begin{array}{c}\text { Crop/vine } \\
(\mathrm{kg})\end{array}$ & $\begin{array}{l}\text { SSC } \\
(\%) \\
\end{array}$ & $\begin{array}{c}\text { Crop/vine } \\
(\mathrm{kg})\end{array}$ & $\begin{array}{l}\text { SSC } \\
(\%) \\
\end{array}$ \\
\hline Clean cultivation & 11.9 & $16.3 \mathrm{ab}$ & 12.6 & 15.8 & 11.9 & 14.2 & 13.6 & 15.2 \\
\hline Budbreak herbicide & 10.8 & $17.0 \mathrm{a}$ & 13.6 & 15.4 & 12.8 & 14.2 & 15.0 & 15.0 \\
\hline Bloom herbicide & 11.3 & $16.0 \mathrm{~b}$ & 12.5 & 15.8 & 11.6 & 14.5 & 14.2 & 15.3 \\
\hline $\begin{array}{l}\text { Budbreak + bloom } \\
\text { herbicide }\end{array}$ & 11.3 & $16.2 \mathrm{ab}$ & 13.8 & 15.4 & 13.0 & 14.2 & 15.7 & 15.2 \\
\hline Training system & & & & & & & & \\
\hline $\begin{array}{l}\text { Not divided (HRU) } \\
\text { Divided (GDC) }\end{array}$ & $\begin{array}{r}9.5 \mathrm{~b} \\
12.9 \mathrm{a}\end{array}$ & $\begin{array}{l}16.7 \mathrm{a} \\
16.0 \mathrm{~b}\end{array}$ & $\begin{array}{l}11.9 \mathrm{~b} \\
14.3 \mathrm{a}\end{array}$ & $\begin{array}{l}15.7 \\
15.5\end{array}$ & $\begin{array}{l}10.9 \mathrm{~b} \\
13.8 \mathrm{a}\end{array}$ & $\begin{array}{l}14.3 \\
14.2\end{array}$ & $\begin{array}{l}12.5 \mathrm{a} \\
16.7 \mathrm{~b}\end{array}$ & $\begin{array}{l}15.5 \mathrm{a} \\
14.8 \mathrm{~b}\end{array}$ \\
\hline
\end{tabular}

'Mean separation within columns by Duncan's multiple range test, $P=0.05$; lack of separation indicates nonsignificance. The floor management $X$ training system interaction was not significant for any category.

Another consideration is the impact of vineyard equipment on soil structure. This point has become especially important since the development of the mechanical harvester, a heavy piece of equipment that must be used when the fruit is ripe, regardless of whether the soil is saturated with water from fall rains. The resulting compaction generally is accepted to be greater in cultivated vineyards than on those maintained in sod, which usually have greater competition for water and nutrients. Trashy cultivation is a method of compromise in which the need to maintain organic matter and reduce erosion is balanced with the need to minimize weed competition. Mulching is a technique that maintains soil quality, minimizes weed competition, and reduces evaporation" of water from the soil surface. However, mulch is expensive to purchase and apply, is often not available, can result in difficult equipment maneuverability during wet seasons, and also may introduce noxious weeds into the vineyard.

The results obtained in the two differing sites used in this study confirm these conflicting goals and offer an alternative solution-weed control with an herbicide that does not have residual soil activity. Expt. 1 was conducted in a commercial vineyard on a site that had been in continuous cultivation for more than 100 years. During that time, much topsoil had been lost to erosion, and organic matter content had been reduced. Because of this situation, vine size at the beginning of the experiment was inadequate to produce large crops (Shaulis and Steele, 1969). During the course of the experiment, average vine size increased by $78 \%$, due to more detailed viticultural management and above average rainfall. However, the increase was not "uniform among treatments. With sodded vines, the increase was $<50 \%$, while with herbicide-treated vines, the increase averaged $>91 \%$. Final vine size was adequate for all but the sodded and clean-cultivated vines. Yields as well as vine size increased during the course of the experiment. The large crop of 1987 may reflect combined effects of management and the abundant rainfall of 1986 on vine size.

At the end of the experiment, mulched vines had the largest cane pruning weight and a high cumulative yield. Mulch is thought to primarily influence vine size by enhancing water availability rather than via organic matter (Beattie, 1955). This idea is consistent with the leaf senescence data that suggested mulched vines to be under less stress than most others, except in 1987. It has been shown that grape roots will penetrate portions of the top soil that are free of roots under cultivation or sod (Morlat et al., 1984; Van Huystteen and Weber, 1980b). This may not only contribute to the reduced water stress, but may explain the diuron injury to leaves of vines growing in mulch. The improved water availability, surface root distribution and direct contribution of $\mathrm{K}$ from the mulch also explains the increase in petiole $\mathrm{K}$ concentration. That increase in turn was probably responsible for the appearance of $\mathrm{Mg}$ deficiency symptoms on mulched vine and for the reduced $\mathrm{Mg}$ petiole concentration. It is well known that $\mathrm{K}$ and $\mathrm{Mg}$ uptake are competitive in vines and many other crops (Cook, 1966).

The data on vine size and leaf senescence also generally support the concept that trashy cultivation is nearly as effective as clean cultivation in removing weed competition. However, all of the herbicide treatments produced results equal to or superior to either trashy or clean cultivation. The grower observed that rutting from equipment was least on sod and herbicide-treated rows and, in wet years, worst on cultivated and mulched rows.

The data for Expt. 2 also support the idea that water relations are a key to understanding the response to vineyard floor management. In this site, where water supply per meter of soil depth was low, but where potential rooting depth was great, no differences were found in vine size or yield among floor management treatments during the course of the experiment.

Overall, the data support the use of no tillage in nonirrigated vineyards. It offers protection from erosion and compaction, as well as minimizing competitive weed growth. Secondary advantages are reduced costs of equipment, energy, and time. In vineyards, or portions of vineyards, where soil erosion has greatly reduced potential rooting depth, mulch appears to have the greatest potential to stimulate vine growth, and the increased costs associated with its use may be justified. However, it must be remembered that these data were obtained during a period of adequate rainfall. Vines might respond differently during seasons when water deficits are important.

\section{Literature Cited}

Beattie, J.M. 1955. Mulch as a management system for grapes. Ohio Agr. Expt. Sta. Bul. 28.

Blevins, R. L., M. Smith, and G. Thomas. 1984. Changes in soil properties under no-tillage, p. 191-230. In: R.E. Phillips and S.H. Phillips (eds. ). No-tillage agriculture principles and practices. VanNostrand Reinhold, New York.

Cook, J.A. 1966. Grape nutrition, p. 777-805. In: N.F. Childers (cd.). Temperate and tropical fruit nutrition. N.F. Childers Horticultural Publications, New Brunswick.

Elia, P. and G. Gay. 1985. Indagine sulle techniche di coltivazione del Suolo nei vigneti del Piemonte. Vignevini 12:27-35.

Fleming, H.K. and R.B. Alderfer. 1956. Cultivation and Concord 
grape production. Pennsylvania State Univ. Agr. Expt. Sta. Bul. 616.

Jordan, T.D., R.M. Pool, T.Z. Zabadal, and J.P. Tomkins. 1980. Cultural practices for commercial vineyards. New York State Agr. and Life Sci. Misc. Bul. 111.

Morlat, R. J., J. Robichet, M. Sigogne, M. Remoue, G. Venin, H. Leon, and C. Asselin. 1984. Influence de la densite de plantation et du mode d'entretien du sol sur l'alimentation minérale de la vigne. Connaissance Vigne Vin 18:83-94.

Phillips, S.H. 1981. No-tillage, past and present, p. 1-6. In: R.E. Phillips, G.W. Thomas, and R.L. Blevins (eds.). No-tillage research: Research reports and reviews. Univ. of Kentucky, Lexington.

Remoue, M. and C. LeMaitre. 1985. Comparison de differences densites de plantation et méthodes de culture du sol (non culture et enherbemont permanent). Connaissance Vigne Vin 19:197-200.
Shaulis, N.J. and R.G.D. Steele. 1969. The interaction of resistant rootstock to the nitrogen, weed control, pruning and thinning effects on the productivity of Concord grapevines. J. Amer. Soc. Hort. Sci. 94:422-429.

Van Huystteen, L. and H.W. Weber. 1980a. The effect of conventional and minimum tillage practices on some soil properties in a dry land vineyard. S. Afr. J. Enol. Vitic. 1:35-45.

Van Huystteen, L. and H.W. Weber. 1980b. The effect of selected minimum and conventional tillage practices in vineyard cultivation on vine performance. S. Afr. J. Enol. Vitic. 1:77-83.

Wander, I.W. 1946. Physical and chemical studies of soils in north central Ohio vineyards. Ohio Agr. Expt. Sta. Bul. 663.

Wilson, B,. 1985. The effects of cover crop and irrigation on vine performance. Proc. Oregon Hort. Sot. 76:112-117. 